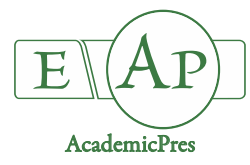

\title{
Antioxidant Capacity, Total Phenols, Total Flavonoids and Colour Component of Cornelian Cherry (Cornus mas L.) Wild Genotypes
}

\author{
Sina COSMULESCU ${ }^{1 *}$, Ion TRANDAFIR ${ }^{2}$, Felicia CORNESCU ${ }^{3}$ \\ ${ }^{1}$ University of Craiova, Faculty of Horticulture, Department of Horticulture and Food Science, 13 A.I. Cuza Street, 200585 Craiova, \\ Romania; sinacosmulescu@hotmail.com (*correspondingauthor) \\ ${ }^{2}$ University of Craiova, Faculty of Sciences, Department of Chemistry, 107 Calea Bucuresti Street, 200529 Craiova, \\ Romania; nelutrandafir@yahoo.com \\ ${ }^{3}$ University of Craiova, Faculty of Horticulture, Doctoral School of Plant and Animal Resources Engineering, 13 A.I. Cuza Street, 200585 \\ Craiova, Romania; felicia_cornescu@yahoo.com
}

\begin{abstract}
A number of selected cornelian cherry wild genotypes were investigated regarding antioxidant capacity, total phenols, total flavonoids and colour component. The total phenolic, total flavonoids and antioxidant activity of methanol extract of cornelian cherry fruits were determined using Folin-Ciocalteu, colorimetric and DPPH methods, respectively. Total phenolic content ranged from 163.69 (S1) to 359.28 (H2) mg GAE $100 \mathrm{~g}^{-1} \mathrm{FW}$. Genotypes $\mathrm{H} 2$ and $\mathrm{H} 3$ had the highest total phenolic content (359.28 and $343.50 \mathrm{mg}$ GAE $100 \mathrm{~g}^{-1} \mathrm{FW}$, respectively), total flavonoids (54.26 and $64.48 \mathrm{mg}^{\mathrm{QE}} 100 \mathrm{~g}^{-1} \mathrm{FW}$, respectively) and antioxidant capacity (2.39 and $2.71 \mathrm{mmolTrolox} 100 \mathrm{~g}^{-1} \mathrm{FW}$, respectively). Significant differences of yellow/blue color component $\left(\mathrm{b}^{*}\right)$, red/ green $\left(\mathrm{a}^{*}\right)$ color component, values of lightness $\left(\mathrm{L}^{*}\right)$ and chroma $(\mathrm{C})$ were obtained for extracts from fruits. The present study shows the potential of certain cornelian cherry genotypes as valuable source of natural antioxidants and gene stock for breeding programs.
\end{abstract}

Keywords: antioxidant activity; cornelian cherry; spontaneous flora; total flavonoids; total phenols

\section{Introduction}

Cornus mas L. (cornelian cherry) is a species from Cornaceae family, native to southern Europe and south western Asia. In Romania it is part of the spontaneous flora and is found in the forests spread on the plains and hills (Cornescu and Cosmulescu, 2017). Commonly, the most frequent use of cornelian cherry fruits is to produce different drinks, syrups, gels, jams and other traditional products. C. mas fruits have been used for centuries as traditional cuisine and folk medicine in various countries of Europe and Asia (Dinda et al., 2016). Plants are valuable sources of bioactive compounds with an important role in nutrition and human health. Among the natural compounds, phenols and flavonoids have been found to be an important part of human diet and are considered as active principles in many herbs. There are investigations regarding the chemical properties of cornelian cherry fruits. C. mas fruits collected in wild flora are a valuable source of natural antioxidants and deserve attention in preservation of genetic and biological diversity (Bajic-Ljubicic et al., 2018). A high number of bioactive compounds have been identified in $C$. mas fruits, among which flavonoids exert favorable health effects, especially by acting as potent antioxidants (Moldovan and David, 2017). Cornelian cherry cultivars have high biological efficiency-antioxidant activity, total phenolic content and content of ascorbic acid (Rop et al., 2010; Hassanpour et al., 2012). According to Pawlowska et al. (2010), it looks like the fruits of cornelian cherry revealed the presence of considerable amounts of flavonoids. Cyanidin-3-rhamnosylgalactoside, cyanidin-3galactoside and delphinidin-3-galactoside, were isolated and identified from the berries of $C$. mas by $\mathrm{Du}$ and Francis (1973). There is a variety of cornelian cherry genotypes with different physical-chemical characteristics. The investigation made by Popovic et al. (2012) show that the fruits are a significant source of phenolic compounds and anthocyanins with high antioxidant activity, which varied greatly among the genotypes. Significant variability has also been found in other constituents as well, such as vitamin C, total sugars, organic acid, flesh lipids, linoleic acid in the seed (Brindza et al., 2007). In most cornelian cherry fruits, studied by Kucharska et al. (2015) differences of origin do affect the quantitative but not the qualitative composition and pelargonidin 3-galactopyranoside was dominant. 
Romania is rich in cornelian cherry populations, and as a result it is important to select spontaneous flora of genotypes with important characteristics, whose commercial cultivation could be successfully practiced. The objective of this research was to examine the antioxidant activity, total phenols and total flavonoids of six cornelian cherry that originate from the spontaneous flora of Romania, in order to identify valuable genotypes as a source of natural antioxidants and gene stock for breeding programs.

\section{Materials and Methods}

\section{Materials}

Materials were obtained from fruits of six genotypes of cornelian cherry selected from spontaneous flora in the following areas in Romania: Strimba-Jiu (S1) and Calaparu (C1 and C2) in the town of Turceni, Gorj county $\left(44^{\circ} 40^{\prime} 0^{\prime \prime} \mathrm{N} 23^{\circ} 23^{\prime} 0^{\prime \prime} \mathrm{E}\right)$ and from the village Hartagani $(\mathrm{H} 1$, $\mathrm{H} 2$ and $\mathrm{H} 3)$, Baita village in Hunedoara county (46 $\left.01^{\prime} 52^{\prime \prime} \mathrm{N} 22^{\circ} 53^{\prime} 34^{\prime \prime} \mathrm{E}\right)$. During 2017, fruits of the above genotypes were picked at the stage of full maturity (consumption ripeness). Each sample consisted of $500 \mathrm{~g}$ of fruits per genotype. All samples were frozen at $-20{ }^{\circ} \mathrm{C}$ until use.

\section{Extraction procedure}

Pulp (50 g) from each cultivar have been finely chopped and then homogenized (using an IKA T-25 ULTRATURRAX mixer-homogenizer); $2 \mathrm{~g}$ of product have been combined with $20 \mathrm{~mL}$ methanol, with $2 \%$ hydrochloric acid and put in sealed polyethylene flasks; and then were kept for 60 minutes at a temperature of $30^{\circ} \mathrm{C}$ under the ultrasounds action.

\section{Determination of total phenol content}

The method described by Cosmulescu et al. (2015) was used to determine total phenolics content in the extracts. The absorbance of mixture was measured at $765 \mathrm{~nm}$ using an Evolution 600 UV/VIS spectrophotometer (Thermo Scientific, USA). Gallic acid was used to prepare the standard curve $(0-250 \mathrm{mg} / \mathrm{L})$. Gallic acid was used as reference standard and results were expressed as gallic acid equivalents in milligrams per $100 \mathrm{~g}$ fresh weight (mg GAE $100 \mathrm{~g}^{-1} \mathrm{FW}$ ).

\section{Total flavonoids content}

Determination of flavonoids was done by aluminum nitrate colorimetric method described by Cosmulescu et al. (2015). Quercetin was used for preparing the standard curve $(0-100 \mathrm{mg} / \mathrm{L})$. The results were expressed as milligrams of quercetin equivalents per $100 \mathrm{~g}$ fresh weight (mg QE $100 \mathrm{~g}^{-1} \mathrm{FW}$ ).

\section{Antioxidant activity}

The scavenging capacity of the 2,2-diphenyl-1picrylhydrazyl (DPPH) free radical was monitored according to the method reported by Cosmulescu et al. (2015). Antioxidant capacity was expressed in mmolTrolox $100 \mathrm{~g}^{-1}$.
Phenolic compounds

HPLC analyses were performed on a Finningan Surveyor Plus system (Thermo Electron Corporation, San Jose, CA, USA) including a vacuum degasser, a Surveyor Plus LCPMPP pump, a Surveyor Plus ASP autosampler, a PDA5P diode array detector with $5 \mathrm{~cm}$ flow cell and a Chrom Quest 4.2 system manager as data processor. Separation was performed using a reversed-phase Hypersil Gold C18 column provided by Thermo Electron Corporation (USA). Chromatographic conditions were similar to those described by Nour et al. (2013), Cosmulescu et al. (2017). Phenolic compounds were expressed in $\mathrm{mg} / 100 \mathrm{~g}$ fresh weight ( $\left.\mathrm{mg} 100 \mathrm{~g}^{-1} \mathrm{FW}\right)$.

\section{Measurement of color by the $C I E L^{*} a^{*} b^{*}$ system}

Absorbance of undiluted samples was measured in quartz cuvettes with a path length of $0.1 \mathrm{~cm}$ from 350 to $850 \mathrm{~nm}$ using an Evolution 600 spectrophotometer (Cosmulescu et al., 2014). L* (lightness), a* (red/green colour component), $\mathrm{b}^{*}$ (yellow/blue colour component) were determined using the color analysis program VLColorCalc. Chroma (C) or saturation and hue angle $(\mathrm{H})$ or tone was determined considering McGuire (1992): $\mathrm{C}=$ $\left(a^{* 2}+b^{* 2}\right)^{1 / 2} ; H=$ arctangent of $b^{*} / a^{*}$.

\section{Statistical analysis}

Results were expressed as mean \pm standard error of three samples analyzed separately. Statistical comparisons between samples were performed with Duncan t-test for independent observations (using Statgraphics Centurion XVI software). Differences were considered significant at $\mathrm{p}$ $<0.05$.

\section{Results and Discussion}

Total phenolics, total flavonoid, individual phenolic compounds and antioxidant capacity

The results obtained have indicated significant differences $(p<0.05)$ in antioxidant capacity, total phenols and total flavonoids content between the genotypes analyzed (Table 1). Total phenolic content ranged from 163.69 (S1) to 359.28 (H2) mg GAE $100 \mathrm{~g}^{-\mathrm{P}}$ FW. A content of $315.3 \mathrm{mg} 100 \mathrm{~g}^{-1} \mathrm{FW}$ phenolics was found by Hashempour et al. (2010) in cornelian cherry genotypes from Iranian native populations. A variation of the content in total phenolic content was also found by Rop et al. (2010) in 12 cultivars of cornelian cherry (2.61 to $8.11 \mathrm{~g}$ GAE $\mathrm{kg}^{-1} \mathrm{FM}$ ). These differences may be due to genetic factors and different ability to synthesize secondary metabolites of genotypes. In this study, the content of polyphenols is higher than the content found by Cosmulescu et al. (2017) in genotypes previously analyzed. According to the results obtained by Cosmulescu et al. (2017), total polyphenols (mg GAE $100 \mathrm{~g}^{-1} \mathrm{FW}$ ) of cornelian cherry (Cornus mas) are lower (184.693), than those of Rosa canina (727.292), Rubus fruticosus (412.385), Hippophae rhamnoides (343.572), Crataegus monogyna (203.011), or Prunus spinosa (192.602). A content of 2.81$5.79 \mathrm{mg} \mathrm{g}^{-1}$ total phenolics was found by Tural and Koca 
392

(2008) in the cornelian cherry fruits. In a study by Pawlowska et al. (2010), the fruits of cornelian cherry revealed the presence of considerable amounts of flavonoids, which supports the antioxidant and nutritional potential of this plant species. In our study, the content of flavonoids differs from one genotype to another and the highest content of total flavonoid was determined in $\mathrm{H} 3$ genotype

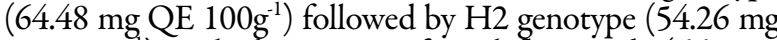
QE $\left.100 \mathrm{~g}^{-1}\right)$. A high content of total flavonoids (669 mg catechin $100 \mathrm{~g}^{-1}$ FW) was found by Hassanpour et al. (2011) in the cornelian cherry genotypes of Iran's spontaneous flora. The DPPH radical scavenging effects of cornelian cherry fruit extracts are given in Table 1 . Among six cornelian cherry types that have different results, the results have a variation between 1.24 and 2.71 mmolTrolox $100 \mathrm{~g}^{-1} \mathrm{FW}$. The variability of total antioxidant activity was equally high (from 3.30 to $9.54 \mathrm{~g} \mathrm{AAE} \mathrm{kg}^{-1} \mathrm{FM}$ ) to 12 cornelian cherry genotypes cultivated in Czech Republic (Rop et al., 2010). According to Table 1, the highest antiradical activity was found H3 genotype (2.71) followed by H2 (2.39). Popovic et al. (2012) believe that cornelian cherry fruits possess high antioxidant activity and that there is a huge variation among $C$. mas genotypes in terms of antioxidant activity. Also, some authors have reported potential antioxidant activity of cornelian cherry leaves and flowers (Stankovic et al., 2014; Hassanpour et al., 2011; Islamovic et al., 2014). Comparing the antioxidant activity of Cornus vs Crataegus extract, antioxidant activity was found to be significantly higher (1.5-1.7 times) for Cornus (Babalica-Petrescu et al., 2014). Among the individual phenolic compounds (Table 2), gallic acids were determined in higher amounts $(14.49 \mathrm{mg} / 100 \mathrm{~g})$, followed by coumaric acid $(13.79 \mathrm{mg} / 100 \mathrm{~g})$, ellagic acid $(5.71 \mathrm{mg} / 100 \mathrm{~g})$, salicylic acid $(1.43 \mathrm{mg} / 100 \mathrm{~g})$, ferulic acid $(1.25 \mathrm{mg} / 100 \mathrm{~g})$ and synaptic acid $(0.19 \mathrm{mg} / 100 \mathrm{~g})$. Milenkovic-Andjelkovic et al. (2015) reported that ellagic acid was predominant phenol acid in cornelian cherry fruit and leaf extracts, followed by chlorogenic and gallic acids.
Other authors also reported the presence of pelargonidin 3O-galactoside, cyanidin 3-O-galactoside and delphinidin 3O-galactoside (Pyrkosz-Biardzka et al., 2014). Also, myricetin $(26.54 \mathrm{mg} / 100 \mathrm{~g})$ and rutin $(3.07 \mathrm{mg} / 100 \mathrm{~g})$ have been determined in cornelian cherry fruit. Rudrapaul et al. (2015) reported one new $\beta$-hydroxychalcone, 4-acetoxy$5,2^{\prime}, 4^{\prime}, 6^{\prime}, \beta$-pentahydroxy-3-methoxychalcone, one new flavanone, 7,3'-dihydroxy-5,4'-dimethoxyflavanone and seven known compounds, 2R, 3R-trans-aromadendrin, naringenin-7-O-methylether, myricetin, quercetin-3-Orutinoside, ursolic acid, gallic acid and d-glucose in methanolic fruit extract of Cornus mas. A wide variability was recorded between genotypes within the same phenolic compound. The variation limits were quite high, indicating that the genotype and environmental factors make their mark on fruit composition (Table 2).

\section{Measurement of color by the $\operatorname{CIEL}^{*} a^{*} b^{*}$ system}

To investigate color of the extracts obtained from the fruits of cornelian cherry, lightness and color components were measured. Table 3 presents the results of color evaluation of the fruits extracts using the CIEL*a*b* color system. Significant differences of yellow/blue color component $\left(b^{*}\right)$, red/ green $\left(a^{*}\right)$ color component, values of lightness $\left(\mathrm{L}^{*}\right)$ and chroma (C) were obtained for extracts from fruits. The maximum for $\mathrm{L}$ (lightness) is 100 , representing a perfectly reflecting diffuser and the minimum is zero which represents black. The $\mathrm{a}^{*}$ and $\mathrm{b}^{*}$ axes have no specific numerical limits, where the positive $\mathrm{a}^{*}$ is red and the negative $\mathrm{a}^{*}$ is green. In the present study, the $\mathrm{a}^{*}$ values were in range of 12.05 to 21.8 , which is higher than those reported by Tural and Koca (2008) (6.25 - 15.59). Positive and negative $b^{*}$ are yellow and blue, respectively (Mohebbi et al., 2009). Values $\mathrm{b}^{*}$ ranged from 10.95 , for samples $\mathrm{H} 2$, to 4.15 , for samples $\mathrm{C} 2$. In other studies $\mathrm{b}^{*}$ values are in range from 6.64 to 8.12 (Islamovic et al., 2014), 1.22 to 11.35 (Drkenda et al., 2014) and from 3.46 and 6.64 (Tural and Koca, 2008).

Table 1. Antioxidant activity, total phenolics content and total flavonoids content of wild cornelian cherry fruits

\begin{tabular}{cccc}
\hline Genotypes & $\begin{array}{c}\text { Total phenolic content } \\
(\mathrm{mg} \mathrm{GAE} / 100 \mathrm{~g} \mathrm{FW})\end{array}$ & $\begin{array}{c}\text { Total flavonoid content } \\
(\mathrm{mg} \mathrm{QE} / 100 \mathrm{~g} \mathrm{FW})\end{array}$ & $\begin{array}{c}\text { Antioxidant activity } \\
(\mathrm{mmolT} \text { rolox } / 100 \mathrm{gW})\end{array}$ \\
\hline $\mathrm{C} 1$ & $262.02 \pm 2.92^{\mathrm{b}}$ & $25.80 \pm 0.24^{\mathrm{b}}$ & $1.64 \pm 0.03^{\mathrm{ab}}$ \\
$\mathrm{C} 2$ & $299.47 \pm 7.86^{\mathrm{c}}$ & $33.40 \pm 1.87^{\mathrm{c}}$ & $2.21 \pm 0.10^{\mathrm{c}}$ \\
H1 & $171.94 \pm 7.44^{\mathrm{a}}$ & $13.77 \pm 0.14^{\mathrm{a}}$ & $1.24 \pm 0.01^{\mathrm{a}}$ \\
H2 & $359.28 \pm 9.57^{\mathrm{d}}$ & $54.26 \pm 1.67^{\mathrm{d}}$ & $2.39 \pm 0.13^{\mathrm{c}}$ \\
H3 & $343.50 \pm 7.33^{\mathrm{d}}$ & $64.48 \pm 0.81^{\text {de }}$ & $2.71 \pm 0.05^{\mathrm{d}}$ \\
S1 & $163.69 \pm 0.04^{\mathrm{a}}$ & $12.14 \pm 0.01^{\mathrm{a}}$ & $1.28 \pm 0.01^{\mathrm{a}}$ \\
Mean & $266.65 \pm 6.84$ & $33.97 \pm 1.74^{\mathrm{c}}$ & $1.91 \pm 0.25^{\mathrm{ab}}$ \\
\hline
\end{tabular}

${ }^{*}$ Data expressed as means \pm SE of three samples analyzed separately. ${ }^{*}$ Different superscript letters within the same column indicate significant differences $(\mathrm{P}<0.05)$

Table 2. Descriptive statistics for individual phenolic compounds in wild cornelian cherry fruits genotypes ( $\mathrm{mg} / 100 \mathrm{~g} \mathrm{FW}$ )

\begin{tabular}{|c|c|c|c|c|c|c|c|c|}
\hline Phenolic compounds & Gallic acid & Coumaric acid & Ferulic acid & Synapic acid & Salicylic acid & Rutin & Ellagic acid & Myricetin \\
\hline Mean & 14.49 & 14.49 & 1.25 & 0.19 & 1.43 & 3.07 & 5.71 & 26.54 \\
\hline Standard Deviation & 8.46 & 12.43 & 0.89 & 0.12 & 0.92 & 2.68 & 5.96 & 3.70 \\
\hline Sample Variance & 71.62 & 154.64 & 0.80 & 0.02 & 0.85 & 7.22 & 35.58 & 13.76 \\
\hline Minimum & 5.29 & 0.42 & 0.12 & 0.05 & 0.40 & 1.18 & 0.15 & 19.80 \\
\hline Maximum & 37.17 & 41.87 & 2.72 & 0.43 & 3.43 & 10.85 & 17.47 & 32.33 \\
\hline Confidence Level(95.0\%) & 5.68 & 8.35 & 0.60 & 0.08 & 0.61 & 1.80 & 4.00 & 2.49 \\
\hline
\end{tabular}


Table 3. CIEL ${ }^{*} \mathrm{~b}^{*}$ parameters for three differently extracts in wild cornelian cherry fruits

\begin{tabular}{|c|c|c|c|c|c|}
\hline \multirow{2}{*}{ Genotypes } & \multicolumn{5}{|c|}{ Parameters } \\
\hline & $\mathrm{L}^{*}$ & $a^{*}$ & $b^{*}$ & $\mathrm{C}=\left(\mathrm{a}^{* 2}+\mathrm{b}^{* 2}\right)^{1 / 2}$ & $\mathrm{H}^{\circ}$ \\
\hline $\mathrm{Cl}$ & $48.8 \pm 1.61^{a}$ & $13.55 \pm 1.95^{\mathrm{d}}$ & $6.20 \pm 0.59^{d}$ & 14.9 & 24.58 \\
\hline $\mathrm{C} 2$ & $44.45 \pm 0.69^{\mathrm{d}}$ & $12.05 \pm 1.29^{\mathrm{e}}$ & $4.15 \pm 1.24^{\mathrm{e}}$ & 12.74 & 19.00 \\
\hline $\mathrm{Hl}$ & $47.5 \pm 1.05^{\mathrm{b}}$ & $16.65 \pm 0.47^{c}$ & $7.75 \pm 0.30^{c}$ & 18.36 & 24.95 \\
\hline $\mathrm{H} 2$ & $48.45 \pm 2.12^{\mathrm{a}}$ & $21.80 \pm 0.89^{\mathrm{a}}$ & $10.95 \pm 0.74^{a}$ & 24.39 & 26.66 \\
\hline $\mathrm{H} 3$ & $46.1 \pm 1.35^{c}$ & $19.80 \pm 0.65^{b}$ & $9.15 \pm 0.94^{b}$ & 21.81 & 24.80 \\
\hline S1 & $46.9 \pm 0.56^{c}$ & $16.60 \pm 1.23^{c}$ & $7.20 \pm 1.03^{c}$ & 18.09 & 23.44 \\
\hline
\end{tabular}
genotypes.

Table 2 shows that lightness $\left(L^{*}\right)$ has values between 44.45 and $48.8 . \mathrm{L}^{*}$ is the indicator of lightness-darkness and the higher it is, the lighter the extracts. Indicators $\mathrm{a}^{*}$ and $\mathrm{b}^{*}$ varies from one genotype to another, the values are positive, thus pointing out a greater contribution of red and yellow components. Together the three parameters lightness $\left(\mathrm{L}^{*}\right)$, saturation $\left(\mathrm{C}^{*}\right)$, hue angle or tone $\left(\mathrm{H}^{\circ}\right)$ all contribute tothe color observedin each sample. Intensity or saturation (C) is higher in the $\mathrm{H} 2$ genotype (24.39) and hue angle $\left(\mathrm{H}^{\circ}\right)$ at the same genotype (26.66). Hue angle presented values between 19.00-26.66 from red purple $\left(0^{\circ}\right)$ to yellow $\left(90^{\circ}\right)$. A value of 39.7 and 20.7 , respectively, was reported by Gunduz et al. (2013) to cornelian cherries fruit for chroma (C) and tone $\left(\mathrm{H}^{\circ}\right)$ in the stage of dark red.

\section{Conclusions}

C. mas fruits collected in wild flora are a valuable source of natural antioxidants and gene stock for breeding programs. The present study shows the potential value of the cornelian cherry germplasm in Romania.

\section{References}

Badalica-Petrescu M, Dragan S, Ranga F, Fetea F, Socaciu C (2014). Comparative HPLC-DAD-ESI (+) MS fingerprint and quantification of phenolic and flavonoid composition of aqueous leaf extracts of Cornus mas and Crataegusmonogyna, in relation to their cardiotonic potential. Notulae Botanicae Horti Agrobotanici Cluj-Napoca42(1):9-18.

Bajic-Ljubicic J, Popovic Z, Matic R, Bojovic S (2018). Selected phenolic compounds in fruits of wild growing Cornus mas L. Indian Journal of Traditional Knowledge 17(1):91-96.

Brindza P, BrindzaJ, Tóth D, KlimenkoSV, Grigorieva O (2007). Slovakian cornelian cherry (Cornus mas L.): potential for cultivation. Acta Horticulturae 760:433-437.

Cornescu F, Cosmulescu S (2017). Morphological and biochemical characteristics of fruits of different cornelian cherry (Comus mas L.) genotypes from spontaneous flora. Notulae Scientia Biologicae 9(4):577-581.

Cosmulescu S, Trandafir I, Nour V (2017). Phenolic acids and flavonoids profiles of extracts from edible wild fruits and their antioxidant properties. International Journal of Food Properties 20(12):31243134.

Cosmulescu S, Trandafir I, Nour V, Botu M (2015). Total phenolic, flavonoid distribution and antioxidant capacity in skin, pulp and fruit extracts of plum cultivars. Journal of Food Biochemistry 39(1):64-69.

Cosmulescu S, Trandafir I, Nour V, Ionica M, Tutulescu F (2014). Phenolics content, antioxidant activity and color of green walnut extracts for preparing walnut liquor. Notulae Botanicae Horti Agrobotanici Cluj-Napoca 42(2):551-555.

Dinda B, Kyriakopoulos AM, Dinda S, Zoumpourlis V, Thomaidis NS, Velegraki A, Dinda M (2016). Cornus mas L. (cornelian cherry), an important European and Asian traditional food and medicine: Ethnomedicine, phytochemistry and pharmacology for its commercial utilization in drug industry. Journal of Ethnopharmacology 193:670690.

Drkenda P, Spahic A, Begic-Akagic A, Gasi F, Vranac A, Blanke M (2014).Pomological characteristics of some autochthonous genotypes of cornelian cherry (Cornus mas L.) in Bosnia and Herzegovina. ErwerbsObstbau 56:59-66.

DuCT, Francis FJ (1973). Anthocyanins from Cornus mas. Phytochemistry 12(10):2487-2489.

Gunduz K, Saracoglu O, Özgen M, Serce S (2013). Antioxidant, physical and chemical characteristics of cornelian cherry fruits (Cornus mas L.) at different stages of ripeness. Acta Scientiarum Polonorum Hortorum Cultus12(4):59-66.

Hashempour A, Ghazvini RF, Bakhshi D, Ghasemnezhad M, Sharafti M, Ahmadian H (2010). Ascorbic acid, anthocyanins, and phenolics contents and antioxidant activity of ber, azarole, raspberry, and cornelian cherry fruit genotypes growing in Iran. Horticulture, Environment and Biotechnology 51(2):83-88.

Hassanpour H, Hamidoghli Y, Samizadeh H (2012). Some fruit characteristics of Iranian cornelian cherries (Cornus mas L.). Notulae Botanicae Horti Agrobotanici Cluj-Napoca 40(1):247-251.

Hassanpour H, Yousef H, Jafar H, Mohammad A (2011). Antioxidant capacity and phytochemical properties of cornelian cherry (Cornus mas L.) genotypes in Iran. Scientia Horticulturae 129(3):459-463.

Islamovic A, Mlaco M, Berbic N, Begic-Akagic A, Orucevic S, Bulbulusic A, Drkenda P (2014). Seasonal variation of the physical and chemical parameters of wild genotypes of cornelian cherry (Cornus mas L.). Agriculture and Food 2:466-471.

Kucharska AZ, Szumny A, Sokol-Letowska A, Piorecki N, Klymenko SV (2015).Iridoids and anthocyanins in cornelian cherry (Cornus mas L.) cultivars. Journal of Food Composition and Analysis 40:95-102.

Mcguire RG (1992). Reporting of objective color measurements. HortScience 27:1254-1255.

Milenkovic-Andelkovic AS, Andelkovic MZ, Radovanovic AN, 
394

Radovanovic BC, Nikolic V (2015). Phenol composition, DPPH radical scavenging and antimicrobial activity of Cornelian cherry (Cornusmas) fruit and leaf extracts. Hemijska Industrija 69(4):331-337.

Mohebbi M, Akbarzadeh-T MR, Shahidi F, Moussavi M, Ghoddusi HB (2009). Computer vision systems (CVS) for moisture content estimation in dehydrated shrimp. Computers and Electronics in Agriculture 69(2):128-134.

Moldovan B, David L (2017). Bioactive Flavonoids from Cornus mas L. fruits. Mini-Reviews in Organic Chemistry 14(6):489-495.

Nour V, Trandafir I, Cosmulescu S (2013). HPLC determination of phenolic acids, flavonoids and juglone in walnut leaves. Journal of Chromatographic Science 51(9):883-890.

Pawlowska AM, Camangi F, Braca A (2010). Quali-quantitative analysis of flavonoids of Cornus mas L. (Cornaceae) fruits. Food Chemistry 119(3):1257-1261.

Popovic BM, Stajner D, Slavko K, Sandra B (2012). Antioxidant capacity of cornelian cherry (Cornus mas L.) - Comparison between permanganate reducing antioxidant capacity and other antioxidant methods. Food Chemistry 134(2):734741.
Pyrkosz-Biardzka K, Kucharska AZ, Sokol-Letowska A, Strugala P, Gabrielska J (2014). A comprehensive study on antioxidant properties of crude extracts from fruits of Berberis vulgaris L., Cornus mas L. and Mahonia aquifolium Nutt. Polish Journal of Food and Nutrition Sciences 64(2):91-99.

Rop O, Mlcek J, Kramarova D, Jurikova T (2010). Selected cultivars of cornelian cherry (Cornus mas L.) as a new food source for human nutrition. African Journal of Biotechnology 9(8):1205-1210.

Rudrapaul P, Kyriakopoulos AM, De UC, Zoumpourlis V, Dinda B (2015). New flavonoids from the fruits of Cornus mas, Cornaceae. Phytochemistry Letters 11:292-295.

Stankovic MS, Zia-Ul-Haq M, Bojovic BM, Topuzovic MD (2014). Total phenolics, flavonoid content and antioxidant power of leaf, flower and fruits from cornelian cherry (Cornus mas L.). Bulgarian Journal of Agricultural Science 20:358-363.

Tural S, Koca I (2008). Physico-chemical and antioxidant properties of cornelian cherry fruits (Cornus mas L.) grown in Turkey. Scientia Horticulturae 116(4):362-366. 